\title{
CONTEXTUAL TEACHING AND LEARNING (CTL) UNTUK MENINGKATKAN KREATIVITAS BERPENDAPAT SISWA PADA PEMBELAJARAN IPS
}

\author{
Rani Oktapiani ${ }^{1}$ \\ Tin Rustini ${ }^{2}$
}

\begin{abstract}
ABSTRAK
Penelitian ini dilatarbelakangi oleh rendahnya kreativitas berpendapat siswa, sehingga pembelajaran menjadi pasif dan tidak adanya interaksi antara guru dengan siswa, pembelajaran hanya berpusat pada guru. PTK ini menggunakan metode yang dikembangkan oleh kemmis dan McTaggart. Penulis menerapkan pendekatan CTL sebagai pembaharuan dalam pembelajaran IPS di kelas IV. Hasil evaluasi kreativitas berpendapat siswa dengan menggunakan pendekatan CTL mengalami peningkatan setiap siklusnya, rata-rata hasil evaluasi kreativitas berpendapat siswa pada siklus I adalah 63, siklus II adalah 72, dan siklus III adalah 76. Rata-rata hasil evaluasi individu siklus I adalah 68, rata-rata hasil evaluasi kelompok siklus I adalah 74, ratarata nilai evaluasi individu siklus II adalah 72, rata-rata hasil evaluasi kelompok siklus II adalah 76, rata-rata hasil evaluasi individu siklus III adalah 83, dan rata-rata hasil evaluasi kelompok siklus III adalah 82. Dengan demikian, dapat disimpulkan bahwa penggunaan pendekatan CTL pada pembelajaran IPS dapat meningkatkan kreativitas berpendapat siswa dan hasil belajar siswa.

Kata kunci: Contextual Teaching and Learrning (CTL), kreativitas berpendapat siswa
\end{abstract}

\section{A. PENDAHULUAN}

Kesadaran tentang pentingnya pendidikan yang dapat memberikan harapan dan kemungkinan-kemungkinan yang lebih baik di masa mendatang, telah mendorong berbagai upaya dan perhatian kita sebagai pendidik terhadap setiap derap langkah dan perkembangan dalam dunia pendidikan. Pendidikan sebagai salah satu upaya dalam rangka meningkatkan kualitas menjadi lebih baik. Pendidikan ini menuntun untuk mempersiapkan kita dalam menghadapi perkembangan Ilmu Pengetahuan dan teknologi (IPTEK).

Pada kenyataannya pendidikan bukanlah suatu upaya yang sederhana, melainkan suatu kegiatan yang dinamis dan penuh tantangan. Salah satu mata pelajaran yang diajarkan di sekolah untuk mempersiapkan peserta didik dalam menghadapi tantangan teknologi di masa sekarang dan akan datang adalah mata pelajaran IPS. Kurikulum 2006 untuk tingkat SD menyatakan bahwa pendidikan IPS bertujuan untuk:

1. Mengenal konsep-konsep yang berkaitan dengan kehidupan masyarakat dan lingkungan,

2. Memiliki kemampuan dasar untuk berfikir logis dan kritis, rasa ingin tahu, inkuiri, memecahkan masalah, dan keterampilan dalam kehidupan sosial,

\footnotetext{
${ }^{1}$ Alumni PGSD UPI Kampus Cibiru

${ }^{2}$ Dosen UPI Kampus Cibiru
} 
3. Memiliki komitmen dan kesadaran terhadap nilai-nilai sosial dan kemanusiaan,

4. Memiliki kemampuan berkomunikasi, bekerja sama dan berkompetisi dalam masyarakat yang majemuk, di tingkat lokal, nasional, dan global.

Dengan demikian tujuan IPS bukan hanya sebagai bidang studi yang memberikan sejumlah materi kepada siswanya, melainkan guru juga di tuntut agar mampu menyajikan materi-materi pembelajaran IPS menjadi lebih bermakna dan menyenangkan. Selain itu guru juga dituntut untuk mengembangkan kemampuan berfikir kritis dan kreatif.

\section{B. TINJAUAN PUSTAKA \\ 1. Hakikat IPS}

Pengertian IPS merujuk pada kajian yang memusatkan perhatian pada aktivitas kehidupan manusia. Berbagai dimensi manusia dalam kahidupan sosialnya merupakan fokus kajian dari IPS. Ilmu Pengetahuan Sosial (IPS) adalah suatu mata pelajaran yang mengajarkan kepada siswa dari mulai SD atau MI, agar mereka dapat mengenal berbagai fenomena-fenomena dunia.

Nursid Sumaatmadja (Supriatna , 2010: 94) berpendapat bahwa 'studi sosial (Sosial Studies) bukan merupakan bidang keilmuan atau disiplin akademis, melainkan lebih merupakan suatu bidang pengkajian tentang gejala dan masalah sosial, untuk mengkaji masalah-masalah sosial'. Tentunya studi sosial lebih bersifat praktis dari pada akademik teoritis. Oleh karena itu pendekatan yang digunakan bersifat interdisipliner, multidisipliner, dan terpadu (Integreted). Dengan demikian, bentuk dan studi sosial lebih banyak menunjukan pada program studi gabungan yang berasal dari berbagai disiplin ilmu.

Tujuan pendidikan IPS dikembangkan atas dasar pemikiran bahwa pendidikan IPS merupakan suatu disiplin ilmu. Oleh karena itu pendidikan IPS harus mengacu pada tujuan pendidikan nasional. Dengan demikian tujuan pendidikan IPS adalah mengembangkan kemampuan peserta didik dalam menguasai disiplin ilmu-ilmu sosial untuk mencapai tujuan pendidikan yang lebih tinggi.

Menurut Hasan (Supriatna, 2010:7), tujuan pendidikan IPS dapat dikelompokan ke dalam tiga kategori, yaitu 'Pengembangan kemampuan intelektual siswa, pengembangan kemampuan dan rasa tanggung jawab sebagai anggota masyarakat dan bangsa serta pengembangan diri siswa sebagai pribadi'.

\section{Contetextual Teaching and Learning (CTL) sebagai Model Pembelajaran IPS SD}

Pembelajaran kontekstual atau Contextual Teaching and Learning (CTL) adalah konsep belajar yang membantu guru mengaitkan antara materi pembelajaran dengan situasi dunia nyata siswa, dan mendorong siswa membuat hubungan antara pengetahuan yang dimilikinya dengan penerapannya dalam kehidupan mereka sehari-hari. Menurut Nurhadi (Sutardi dan Sudirjo,2007:95) 'pengetahuan dan keterampilan siswa diperoleh dari usaha siswa mengkonstruksi sendiri pengetahuan dan keterampilan baru ketika ia belajar'. Selanjutnya Sanjaya ( Sutardi dan Sudirjo,2007:95), mengemukakan bahwa:

Pembelajaran kontekstual adalah suatu pendekatan pembelajaran yang menekankan kepada proses keterlibatan siswa secara penuh untuk dapat 
menemukan materi yang dipelajari dan menghubungkannya dengan situasi kehidupan nyata, sehingga mendorong siswa untuk dapat menerapkannya dalam kehidupan sehari-hari.

Model pembelajaran kontekstual di sekolah dasar, pada hakikatnya merupakan konsep belajar yang membantu guru dengan cara mengaitkan materi yang diajarkan dengan situasi nyata siswa, dan mendorong siswa untuk membuat hubungan antara pengetahuan yang dimilikinya dengan penerapannya dalam kehidupan mereka sehari-hari dengan melibatkan tujuh komponen pembelajaran efektif. Komponen model pembelajaran di sekolah dasar, pada prinsipnya menerapkan tujuh komponen utama pembelajaran efektif. Ketujuh komponen tersebut yaitu kontruktivisme (Constructivism), menemukan (Inquiry), bertanya (Questioning), masyarakat belajar (Learning Community), pemodelan (Modeling),refleksi (Reflection), penilainan sebenarnya (Authentic Assesment).

Robert E. Yager (Rosalin, 2008:17-18) mengemukakan bahwa 'Langkah-langkah atau tahapan model kontekstual meliputi empat tahapan, yaitu: tahap invitasi, tahap eksplorasi, tahap penjelasan dan solusi, serta tahap pengambilan tindakan'.

\section{Kreativitas Berpendapat Siswa}

Kreativitas menurut Barron (Ali dan Asrori, 2008:41) 'Adalah kemampuan untuk menciptakan sesuatu yang baru'. Sedangkan Munandar ( Ali dan Asrori, 2008:41) mendefinisikan 'Kreativitas adalah kemampuan yang mencerminkan kelancaran, keluwesan, dan orsinilitas dalam berfikir serta kemampuan untuk mengelaborasi suatu gagasan'. Selanjutnya Rogers (Ali dan Asrori, 2008:42) mendefinisikan'Kreativitas sebagai proses munculnya hasil-hasil baru kedalam suatu tindakan'. Hasil-hasil baru ini muncul dari sifat-sifat individu yang unik yang berinteraksi dengan individu lain, pengalaman maupun keadaan hidupnya. Kreativitas ini dapat terwujud dalam suasana kebersamaan dan terjadi apabila relasi antar individu ditandai oleh hubungan-hubungan yang bermakna.

Aspek-aspek mendasar yang menjadi unsur penyusunan suatu kreativitas adalah lancar (Fluency), luwes (Flexibel), asli (Orisinil), dan adanya elaborasi (Elaboration). Berikut penjelasan Munandar (2012:192) tentang ciri-ciri dari setiap aspek kreativitas:

1. Fluency (kelancaran), yang ditandai oleh:

a. Mencetuskan banyak gagasan, jawaban, penyelesaian masalah atau pertanyaan,

b. Memberikan banyak cara atau saran untuk melakukan berbagai hal,

c. Selalu memikirkan lebih dari satu jawaban,

d. Bekerja lebih cepat dan melakukan lebih banyak daripada anak-anaklain.

e. Arus pemikiran lancar

2. Flexibility (keluwesan), yang ditandai oleh:
a. Menghasilkan gagasan, jawaban atau pertanyaan yang bervariasi,
b. Dapat melihat suatu masalah dari sudut pandang yang berbeda,
c. Mencari banyak alternatif atau arah yang berbeda-beda,
d. Mampu merubah cara pendekatan atau pemikiran.
e. Arah pemikiran yang berbeda-beda 
3. Originality (keaslian), yang ditandai oleh:

a. Mampu melahirkan ungkapan yang baru dan unik,

b. Memikirkan cara yang tidak lazim untuk mengungkapkan diri,

c. Mampu mengungangkapkan kombinasi-kombinasi yang tidak lazim dari bagian-bagian atau unsur-unsur,

d. Menggunakan kata-kata atau istilah yang tidak lazim, dan isi jawaban besifat konseptual.

4. Elaboration (penguraian), yang ditandai oleh:

a. Mampu memperkaya dan mengembangkan, menambahkan suatu gagasan atau produk,

b. Memperinci detail-detail dari suatu objek, gagasan, atau situasi sehingga jadi lebih menarik,

c. Setiap jawaban disertai contoh,

d. Uraian jawaban tidak sekedar bersifat garis besar dan pengungkapan gagasan menggunakan kalimat lengkap.

e. Memperluas suatu gagasan

Sehubungan dengan pengembangan kreativitas siswa, (Munandar, 2012:45-46) "meninjau empat aspek dari kreativitas, yaitu pribadi (Person), pendorong atau motivasi (Press), proses (Process), dan produk (Product) (4P dari kreativitas)".

Menurut Munandar (2012: 58-59) kreativitas atau bakat kreatif dapat diukur melalui beberapa pendekatan yaitu:"Pengukuran tes kreativitas secara langsung, tes yang mengukur unsur-unsur kreativitas, pengukuran potensi kreatif secara non-test, dan pengamatan langsung terhadap kinerja kreatif".

\section{Hasil Belajar Siswa}

Hasil belajar merupakan kulmunasi dari suatu proses yang telah dilakukan dalam belajar. Kulmunasi akan selalu diiringi dengan kegiatan tindak lanjut. Hasil belajar harus menunjukan suatu perubahan tingkah laku atau perolehan prilaku yang baru dari siswa yang bersifat menetap, fungsional, positif, dan disadari.

Menurut Benyamin Bloom (Anitah, 2007: 83) menyatakan ' yang dapat menunjukan gambaran hasil belajar mencakup aspek kognitif, afektif, dan psikomotorik'. Sedangkan menurut Romizoswki (Anitah, 2007:83) menyebutkan dalam skema kemampuan yang dapat menunjukan hasil belajar yaitu:

a. Keterampilan kognitif yang berkaitan dengan kemampuan memecahkan masalah dan berfikir logis,

b. Keterampilan psikomotor berkaitan dengan kemampuan tindakan fisik dan kegiatan perseptual,

c. Kemampuan reaktif berkaitan dengan sikap, kebijaksanaan, perasaan dan self control,

d. Keterampilan berkaitan dengan kemampuan sosial dan kepemimpinan.

Menurut Gagne (Anitah, 2007:83) menyebutkan 'Ada lima tipe hasil belajar yang dapat dicapai oleh siswa diantaranya motor skills, verbal information, intelectual skills, attitudes, dan cognitive strategies'. 


\section{METODOLOGI PENELITIAN}

Pelaksanaan penelitian tindakan kelas ini dilaksanakan di SD Negeri Panawa I Desa Panawa Kecamatan Pamulihan Kabupaten Garut. Subjek penelitian adalah siswa kelas IV sebanyak 16 orang dengan siswa laki-laki sebanyak 9 orang dan siswa perempuan sebanyak 7 orang. Sedangkan yang dijadikan fokus penelitian kelas ini adalah model pembelajaran Contextual Teaching and Learning (CTL) dalam pembelajaran IPS tentang konsep Teknologi Produksi, Komunikasi, dan Transportasi.

Desain penelitian ini menggunakan model yang dikembangkan oleh Kemmis dan Mc Taggart, prosedur penelitiannya terdiri dari tiga siklus, tiap siklus dilaksanakan sesuai dengan perubahan yang ingin dicapai. "Desain Kemmis ini menggunakan model yang dikenal dengan spiral refleksi diri yang dimulai dengan rencana, tindakan, pengamatan, refleksi, dan perencanaan kembali" (Hermawan, 2010:142).

\section{D.HASIL PENELITIAN DAN PEMBAHASAN}

\section{Hasil Penelitian}

\section{a) Siklus I}

Pembahasan pada tindakan 1, 2, dan 3 tentang pembelajaran IPSkonsep Teknologi Produksi dengan menggunakan pendekatan CTL, siswa dikelompokkan menjadi 4 kelompok, setiap kelompok berjumlah 4 orang. Pada siklus I belum semua siswa aktif dalam pembelajaran, masih ada siswa yang duduk diam saja tanpa ada kemauan untuk menjawab atau bertanya kepada guru. Kreativitas berpendapat siswa belum terlihat pada siklus I. Rata-rata nilai kreativitas berpendapat siswa pada siklus I adalah 63. Hasil belajar siswapun masih kurang memuaskan, masih banyak siswa yang nilainya kurang. Nilai rata-rata individu siklus I adalah 68, dan nilai ratarata kelompok 74 .

\section{b) Siklus II}

Berdasarkan lembar observasi, wawancara, dan catatan lapangan, pelaksanaan siklus II tindakan 1, 2, dan 3pembelajaran konsep teknologi komunikasi dengan menggunakan pendekatan CTLsudah mengalami peningkatan dibandingkan dengan siklus sebelumnya. Hal ini terlihat dari adanya kerjasama yang baik dan adanya interaksi antar sesama kelompok, semua siswa aktif ketika diskusi kelompok, adanya kemauan siswa dalam mengemukakan pendapat dan menjawab pertanyaan yang diajukan oleh guru, serta adanya peningkatan dari hasil kerja kelompok dan tes individu. Kreativitas berpendapatpun mengalami peningkatan siswa sudah mampu mengemukakan pendapat sesuai dengan indikator kreativitas. Nilai rata-rata kreativitas berpendapat siklus II adalah 72. Rata-rata hasil evaluasi individu siklus II adalah 72, rata-rata hasil evaluasi kelompok siklus II adalah 76.

\section{c) Siklus III}

Pada pembelajaran siklus III tindakan 1, 2, dan 3pembelajaran konsep Teknologi Transportasi semua siswa sudah aktif dan merespon pertanyaan yang diajukan oleh guru, semua siswa terlibat dalam pembelajaran, tidak ada lagi siswa 
yang mengobrol ketika pembelajaran sedang berlangsung, semua siswa menyimak ketika guru dan narasumber manyampaikan informasi.

Ketika siswa mengemukakan pendapat, sudah terlihat kelancaran dan keluwesan, siswa sudah mampu mengemukakan pendapat atau gagasana yang mereka miliki untuk diungkapkan kepada orang lain. Ketika siswa lain mengungkapkan pendapatnya, siswa lain menanggapi dan terjadi curah pendapat antar siswa yang lain, hal ini membuat kelas menjadi lebih menyenangkan dan bermakna bagi siswa. Hasil rata-rata kreativitas berpendapat siswa pada siklus III adalah 76. Rata-rata hasil evaluasi individu siklus III adalah 83, dan rata-rata hasil evaluasi kelompok siklus III adalah 82.

\section{E. KESIMPULAN DAN SARAN}

\section{Kesimpulan}

Kesimpulan yang dapat diambil dari hasil penelitian ini adalah sebagai berikut:

1. Proses pembelajaran IPS dengan pendekatan CTL dapat dilaksanakan dalam kegiatan pembelajaran, pembelajaran dilaksanakan secara berkelompok. Kelompok dibuat secara heterogen baik dari segi kemampuan maupun jenis kelamin. Pada siklus I aktifitas siswa masih kurang aktif, siswa kurang merespon pertanyaan yang diajukan oleh guru, dalam kegiatan diskusi kelompok belum terlihat adanya kerjasama yang baik. Pada siklus II aktifitas siswa sudah jauh lebih baik daripada siklus sebelumnya, siswa aktif menjawab pertanyaan yang diajukan oleh guru, kerjasama dalam kelompok sudah terjalin dengan baik. Pada siklus III keaktifan siswa sudah baik dibandingkan siklus sebelumnya. Kerjasama antar kelompok sudah terjalin dengan baik semua siswa ikut andil dalam kegiatan diskusi kelompok.

2. Pembelajaran dengan menggunakan pendekatan CTL mampu meningkatkan kreativitas berpendapat siswa, selama pembelajaran menggunakan pendekatan CTL telah mengalami peningkatan pada setiap siklusnya. Temuan pada siklus I menunjukan kreativitas berpendapat siswa masih kurang, dikarenakan siswa belum terbiasa mengemukakan pendapat/gagasan kepada orang lain. Pada siklus 2 kreativitas berpendapat siswa mulai muncul beberapa siswa mampu mengemukakan pendapat dengan lancar, luwes, dan mampu memberikan contoh pada setiap gagasan yang ia kemukakan. Pada sisklus III semua siswa mampu mengemukakan pendapat sesuai dengan indikator kreativitas yaitu fluency dan flexibility. Hasil rata-rata evaluasi kreativitas berpendapat siswa pada siklus I adalah 63, rata-rata nilai evaluasi kreativitas berpendapat siswa pada siklus II adalah 72, dan rata-rata nilai avaluasi kreativitas berpendapat siswa siklus III adalah 76. Siswa sangat antusias mengikuti pembelajaran, ketika materi dikaitkan dengan lingkungan kehidupan mereka sehari-hari dan siswa tidak malu untuk mengemukakan pendapatnya. Dalam kegiatan diskusi kelompok pun mengalami peningkatan dari tiap siklusnya, siswa mampu bekerjasama dengan teman kelompoknya, aktif berinteraksi, kelompok tidak lagi didominasi oleh siswa yang pintar saja. Percaya diri siswa terus meningkat hal ini terlihat ketika siswa mempresentasikan hasil diskusi kelompoknya di depan kelas. 
3. Hasil belajar siswa pada pembelajaran IPS setelah menggunakan pendekatan CTL menunjukan adanya peningkatan pada setiap siklusnya. Hal ini terbukti dari hasil evaluasi secara individual dan kelompok pada setiap tindakan. Adapun hasil ratarata evaluasi secara individual sebagai berikut: siklus I, rata-rata evaluasi individu adalah 68, siklus II rata-rata evaluasi individu adalah 72, siklus III rata-rata evaluasi individu adalah 83. Nilai rata-rata evaluasi kelompok siklus I adalah 74, siklus II rata-rata kelompok adalah 76, dan rata-rata kelompok siklus III adalah 82.

\section{Saran}

Dalam kegiatan pembelajaran guru harus menyajikan beberapa metode atau pendekatan dalam belajar. Penggunaan pendekatan CTL sangat baik kalau dilaksanakan di sekolah dasar sebagai pembaharuan dalam pembelajaran, karena membantu guru dalam proses pembelajaran, proses pemelajaran menjadi lebih baik dan pembelajaran lebih bermakna bagi siswa. Dengan menggunakan pendekatan CTL, semua siswa menjadi aktif dan kreatif ketika pembelajaran berlangsung karena siswa terlibat secara langsung dalam kegiatan pembelajaran.

Penggunaan pendekatan CTL perlu dijadikan model alterntaif dalam upaya meningkatkan aktivitas siswa secara optimal, sehingga siswa terlibat secara aktif dalam pembelajaran, siswa mampu mengemukakan pendapatnya dan pembelajaranpun menjadi lebih bermakna bagi siswa. Dengan pendekatan CTL siswa menjadi termotivasi dalam belajar sehingga dapat meningkatkan hasil belajar siswa.

\section{DAFTAR PUSTAKA}

Ali, M. dan Asrori, M. (2008). Psikologi remaja: perkembangan peserta didik. Edisi ke empat. Jakarta: PT Bumi Aksara

Anitah, S. (2007). Strategi Pembelajaran di SD. Edisi ke satu. Jakarta: Universitas Terbuka

Badan Standar Nasional Pendidikan (BNSP). (2006). Kurikulum 2006. Jakarta: Media Makmur Jaya Mandiri

Hermawan, R. Mujono. dan Suherman, A. (2010). Metode Penelitian Pendidikan SD. Edisi kedua. Bandung: UPI PRESS

Munandar, U. (2012). Pengembangan Kreativitas Anak Berbakat. Jakarta: PT Rineka Cipta

Rosalin, E. (2008). Gagasan Merancang Pembelajaran Kontekstual. Bandung:PT. Karsa Mandiri Persada

Supriatna, N. et al. (2010). Pendidikan IPS SD. Bandung : UPI PRESS

Sutardi, D. dan Sudirjo, E. (2007). Pembaharuan dalam PBM di SD. Edisi kesatu. Bandung : UPI PRESS 